\title{
Progressive MS Trials: Lessons Learned
}

Carmen Tur ${ }^{1,2}$ and Xavier Montalban ${ }^{2}$

${ }^{1}$ Queen Square MS Centre. Department of Neuroinflammation. UCL Institute of Neurology.

2 Department of Neurology-Neuroimmunology and Multiple Sclerosis Centre of Catalonia (Cemcat), Hospital Universitari Vall d'Hebron, Universitat Autònoma de Barcelona. Barcelona, Spain.

\section{Word count:}

Abstract: 200 words; Main text: 2830 words; Number of references: 49; Number of tables: 2.

\section{Disclosures:}

C. Tur has received a post-doctoral research ECTRIMS fellowship (2015). She has also received honoraria and support for travelling from Teva Pharmaceuticals Europe and Ismar Healthcare.

X. Montalban has received speaking honoraria and travel expenses for scientific meetings, has been a steering committee member of clinical trials or participated in advisory boards of clinical trials in the past years with Bayer Schering Pharma, Biogen Idec, Merck Serono, Genentech, Genzyme, Novartis, Sanofi-Aventis, Teva Pharmaceuticals, GSK, Roche, Almirall, NMSS and MSIF. Editor for Clinical Cases for MSJ. 


\section{ABSTRACT}

Up to very recently, no treatments had proved effective in progressive multiple sclerosis (MS). In 2016, four drugs, two tested in phase 3 and two in phase 2 trials, showed a beneficial effect in primary or secondary progressive MS. Although this could indicate a turning point in progressive MS treatment, most of these successes have been modest and mainly restricted to patients with active inflammation, in the context of trials with powerful anti-inflammatory agents. In April 2017, an International Panel of experts in MS met to discuss the reasons behind the recent successes and past failures in progressive MS trials. This paper summarises these reasons, particularly focusing on the main lessons learned for the design of future trials. First, drugs' mechanism of action should tackle the specific pathogenic mechanisms that characterise progressive MS. Secondly, trial populations where new drugs are to be tested should be carefully chosen, possibly including younger patients with shorter disease durations, which have greater chances of showing active deterioration during the trial, therefore increasing the power to detect treatment effects. Thirdly, outcome measures used in future phase 2 and phase 3 trials should be highly sensitive and be accompanied by smart trial designs. 


\section{INTRODUCTION}

Up to very recently, no treatments had proved effective in progressive MS (PMS). In 2016, though, four drugs, two tested in phase 3 trials $^{1,2}$ and two in phase 2 trials $^{3,4}$ showed a beneficial effect in PPMS or SPMS. This change in direction has prompted the revision of the reasons underlying recent chain of successes and past failures.

In this paper, we aim to focus on those reasons behind past failures and recent successes. First, we will focus on the drugs tested in past PMS trials, most of them not specifically designed to tackle the pathogenic mechanisms that characterise the PMS phenotype. Second, we will discuss the type of patient included in PMS trials, which has probably had an enormous influence over the observed results. Finally, we will mention some methodological issues of these trials, mainly related to outcome measures and trial designs, that could have played a role in past failures as well as in recent achievements.

\section{DRUGS IN PROGRESSIVE MS TRIALS}

Many of the drugs that have been tested in PMS trials were not initially designed to tackle the specific pathogenic mechanisms that characterise the PMS phenotype. Instead, they tended to be the same as those tested in RRMS trials (Tables $\mathbf{1}$ and 2). This could be justified by the fact that all pathological traits in MS are thought to coexist throughout the disease, as part of a continuum, being the differences between stages or phenotypes more quantitative than qualitative ${ }^{5,6}$. However, these differences, even if relatively small, may have played a part in the negative results found so far in PMS trials. In addition, the rationale for some of the phase 3 trials carried out in PMS was provided by the results of phase 2 studies performed in RRMS $^{7-9}$ (not in PMS) or by the post-hoc subgroup analyses of PMS trials which had 
overall had negative results ${ }^{10-12}$. Therefore, the non-optimal choice of the drug might have been aggravated by the performance of large phase 3 trials without a previous phase 2 trial in progressive MS with the same drug, which could have helped to save time and economic resources.

However, not all drugs tested in PMS have failed to show a beneficial effect in delaying disability progression. In 1998, the European Study Group on interferon beta (IFN)-1b in SPMS published the results of the first phase 3 trial in SPMS $^{9}$ (i.e. the EUSPMS trial), and these were positive for the primary endpoint (Table 1). Additionally, mitoxantrone, a powerful anti-inflammatory treatment, also showed a beneficial effect in a phase 3 trial with SPMS patients, published in $2002^{13}$. Unfortunately, though, despite these initially promising results, the use of IFNb or mitoxantrone in PMS has been progressively reduced in the clinic, for different reasons. With regard to IFNb, the initial positive results could not be confirmed by the rest of the phase 3 trials also carried out with IFNb in SPMS ${ }^{14-16}$ or PPMS ${ }^{17,18}$. This was attributed to EUSPMS trial population being younger and with higher inflammatory activity, i.e. more similar to the RRMS phenotype, than other trial populations ${ }^{19}$. This implied a loss of confidence in the use of IFNb for SPMS, for which it had been approved in some countries, especially in those patients without any clear evidence of acute macroscopic inflammation, visible with T2-weighted MRI sequences. In relation to mitoxantrone, it is its poor safety profile 20 that has limited its use, which is nowadays almost anecdotal in western countries.

In 2014, the scenario of treatments for MS started to change when the results of the phase 2 MS-STAT trial, which evaluated the efficacy of high doses of simvastatin versus placebo in SPMS, were published ${ }^{4}$. Simvastatin showed an ability to reduce the rate of brain volume loss, the primary outcome, and to delay the 
progression of disability ${ }^{4,21}$. Remarkably, unlike the IFNb and the mitoxantrone trials, the choice of the drug in the MS-STAT trial was based on a careful evaluation of its possible neuroprotective effects ${ }^{22}$.

In 2016, the results of the phase 3 ORATORIO trial were published ${ }^{1}$, meaning the major breakthrough in PMS treatment. The ORATORIO trial showed a clear superiority of ocrelizumab, an anti-CD20 monoclonal antibody, as compared to placebo, in delaying the accrual of disability in patients with PPMS. Remarkably, it was the first time that a drug showed efficacy in PPMS ${ }^{1}$. In this case, although no evidence from any phase 2 trials of ocrelizumab in PMS was available before the start of the trial, several studies had already shown a potential role of CD20 B-cells in the pathogenesis of progressive $\mathrm{MS}^{23-25}$. B-cells accumulate in the subarachnoid space of patients with PMS, in the so-called meningeal follicles ${ }^{23-25}$, and this constituted the main rationale for the ORATORIO trial. Additionally, a post-hoc subgroup analysis of the OLYMPUS trial (published in 2009) had shown some beneficial effect of rituximab, another anti-CD20 monoclonal antibody similar to ocrelizumab, in younger PPMS patients with inflammatory activity ${ }^{26}$. So, although the OLYMPUS trial had been deemed overall negative, the results of this subgroup analysis also contributed to the rationale for the use of ocrelizumab in the ORATORIO trial.

The biotin trial for PMS, also published in 2016, showed as well significant results in the primary endpoint ${ }^{3}$. As happened in the ORATORIO trial, the rationale for the use of biotin was not its efficacy in RRMS, but its unique mechanism of action: biotin activates carboxylases which enhance either the synthesis of fatty acids, therefore supporting myelin repair, or the energy production in neurons, therefore protecting against hypoxia-driven axonal degeneration ${ }^{27}$. 
Finally, the phase 3 EXPAND trial of siponimod in SPMS, presented at ECTRIMS 2016, has also shown a beneficial effect versus placebo², contributing to the list of recent trials successful in PMS. Here, although the drug had proved effective in a phase 2 RRMS trial (BOLD study) and had a clear anti-inflammatory effect $^{28}$, it also seemed to have neuroprotective effects within the CNS after crossing the blood-brain barrier 29 . This latter characteristic constituted the main rationale for its use in SPMS ${ }^{4}$.

Thus, it seems that with all these recent successes, a new era of PMS trials might have started. However, a few considerations need to be made. First, unfortunately, a careful selection of the drug has not always meant obtaining significant results. A clear example is the phase 3 INFORMS trial with fingolimod, a drug with a similar profile to that of siponimod, which failed to show efficacy in $\mathrm{PPMS}^{8}$. Second, since most of the successful drugs in PMS also had a clear direct anti-inflammatory effect, it could be argued that this was in fact the main responsible for their success, rather than their neuroprotective effect. In fact, even in those trials with positive results, the benefits have been modest and have been predominantly restricted to patients with active inflammation, indicating that effective therapies positively impacting the pathophysiology of later stages of progressive MS are still elusive. Therefore, more research into the pathogenic mechanisms of PMS and the mechanisms of action of the potential drugs for PMS is still needed.

\section{TRIAL POPULATIONS}

The choice of the trial population is crucial to be able to capture treatment effects, should they exist. There are at least two potential causes of an eventual unfortunate choice of trial population: first, the lack of an appropriate definition of progressive 
MS; second, the ignoring of patients' disease severity when defining the inclusion criteria.

In relation to the definition problem, in 1996, Lublin and Reingold published the first definitions of MS phenotypes ${ }^{30}$. These could be homogeneously used across the scientific community and meant a significant improvement in trial design ${ }^{30}$. However, the lack of precision of the definitions of SPMS and PPMS, which could not easily incorporate the presence of clinical or MRI activity, prompted the publication of the new definitions of the progressive forms of MS, in $2014^{6}$. These allowed us to use MS disease modifiers to specify whether the patient had clinical/MRI inflammatory activity or active progression, on top of the diagnosis of SPMS or PPMS, which could be very useful for future trial selection.

The problem related to ignoring patients' severity in the inclusion criteria has started to be tackled more recently. A trial population with slower disease progression than that considered when estimating the required sample size may not be powered to detect differences between groups, should they exist. For instance, when in 2007 the phase 3 PROMISE trial was published ${ }^{31}$, one of the reasons attributed to its negative results was the low progression rate in the placebo arm, which was not predicted when designing the trial. A strategy used to avoid unexpected low rates of progression of disability has been the inclusion of patients with greater chances of having an active disease over the course of the trial. This was the strategy of the ORATORIO trial ${ }^{1}$. In this study, one of the inclusion criteria was to have a relatively short disease duration, especially if the patient was not too disabled. This ensured that only patients with steeper accrual of disability were included. However, high progression rates have also been seen in negative studies, such as the INFORMS trial, where the proportion of patients with progression in the 
placebo arm was $70 \%^{8}$. This suggests that other factors apart from the presence of high progression rates may have also been involved in the success of the ORATORIO trial. In fact, in the ORATORIO trial, an additional inclusion criteria was that patients had to be 55 years old or younger, whereas previous studies had allowed the inclusion of patients with ages up to $65^{31}$. So, this younger trial population ensured the participation of patients with greater inflammatory activity ${ }^{1}$, more likely to respond to anti-inflammatory treatment regimes. Of note, although the ORATORIO trial did not show any statistical differences between subgroups defined by inflammatory activity, this was attributed to the lack of power ${ }^{1}$. Thus, it may be possible that the success in the ORATORIO trial was more strongly related to the presence of a population with a more inflammatory phenotype ${ }^{1}$, possibly as a consequence of choosing younger participants, than to the presence of high progression rates, although both may have contributed.

In general, these trials where the study populations are carefully selected to increase their power are considered 'enriched' trials. Importantly, despite the advantages of enriched trials, they may also entail some drawbacks, such as questioning the generalisability of the results to all PMS patients, with and without the trial population features. An alternative to enriched trials may be the performance of subgroup analyses within the trial population to assess whether the efficacy of a drug is similar in different subpopulations. Subgroup analyses are generally performed if previously defined in the trial protocol. In that case, the trial is usually adequately powered for that. Nevertheless, if there is a scientific rationale, it is not inappropriate to conduct a subgroup analysis that was not previously defined in the trial protocol. Thus, it may be reasonable to approach these post-hoc analyses as exploratory and recognise their limited power. 


\section{OUTCOME MEASURES AND TRIAL DESIGNS}

Phase 3 trials in PMS have clinical measures as primary endpoints. Among these, the EDSS-related measures are the most widely used (see Tables 1 and 2). However, the EDSS has limitations ${ }^{32-34}$, which may well have been responsible for the lack of significant results in PMS trials.

Over the years, phase 3 trials in progressive MS have tried different strategies to overcome the limitations of the EDSS. One of these was to substitute the EDSS by another clinical score with a greater sensitivity to clinical progression, such as the Multiple Sclerosis Functional Composite (MSFC) score $^{33}$, which reflects better than the EDSS the upper limb and cognitive functions. For instance, the IMPACT study, which in 2002 showed a beneficial effect of IFNb-1a in SPMS when compared to placebo, had used the changes in MSFC scores during the trial as primary endpoint. Another strategy to overcome the limitations of the EDSS has consisted of using composite outcomes of clinical progression instead of a single score. For example the MIMS (mitoxantrone, SPMS) ${ }^{13}$, the CUPID (dronabinol, SPMS) ${ }^{35}$, the ASCEND (natalizumab, SPMS) ${ }^{36}$ and the INFORMS (fingolimod, PPMS) ${ }^{8}$ trials used composite measures of clinical progression, always involving the EDSS. Nevertheless, despite the use of composite primary endpoints, only the MIMS study $^{13}$ of all these was significant. Also following this strategy, in the ORATORIO study, the composite NEP (no evidence of progression) was used as an exploratory secondary endpoint ${ }^{1}$, emulating the commonly used NECA (no evidence of clinical activity) and NEDA (no evidence of disease activity) for RRMS trials ${ }^{37-40}$. In the 
ORATORIO study, significant treatment effects were not only seen in the primary endpoint, but also in the NEP endpoint: the proportion of patients without progression in the EDSS, NHPT and TWT (all three) was higher among those receiving ocrelizumab than in the placebo $\mathrm{arm}^{1}$. A final strategy has resided in changing completely the focus of the outcome measure from clinical progression to clinical improvement. Although 'percentage of patients with clinical improvement' had been already used as secondary endpoint in a few RRMS trials such as the phase 3 Copolymer- $1^{41}$ and CARE-MS $\|^{39}$, it was used as primary endpoint for the first time in the biotin trial for progressive $\mathrm{MS}^{3}$ (Table 1). Of note, although the use of improvement of disability (instead of delayed progression) as trial primary endpoint is still debatable, it is possible that it reflects a genuine aspect of some drugs for progressive MS. This would be especially true for drugs with a neuroprotective or restorative mechanism of action, as was the case for biotin ${ }^{3,27,42}$.

Phase 2 trial endpoints mainly consist of non-clinical outcome measures. In progressive MS, the most widely used is the brain atrophy rate, which in the MSSTAT trial was the responsible for the differences between treatment groups in favour of simvastatin ${ }^{21}$. On the other hand, its responsiveness is still limited and great efforts are being made to develop new phase 2 outcome measures able to detect treatment effects in 6-12 months, instead of the conventional 24 months (Tables 1 and 2 $^{43,44}$. Along these lines, the recently completed SPRINT-MS trial, apart from aiming at the comparison of ibudilast versus placebo to delay the disability accumulation in SPMS and PPMS, aimed at head-to-head comparisons of several imaging measures in terms of their ability to reflect treatment effects ${ }^{45}$.

Regarding the trial design, the vast majority of the PMS trials -and of the MS trials in general- so far have used the classic 1:1 scheme, where one active arm is 
compared to one placebo arm. And in those few trials with two active arms compared to one placebo $\operatorname{arm}^{13,16,17,46}$, the two active arms tested two doses of the same drug, rather than two active components (Tables 1 and 2). Recent evidence from Oncology trials suggests that this trial design could be improved by comparing several active drugs to the placebo $\mathrm{arm}^{47}$. Following this innovative multi-arm trial suggestion, the phase 2 MS-SMART study was born. It aimed to compare three active drugs, fluoxetine, amiloride and riluzole, to placebo, in a proof-of-concept drug-repurposing four-arm placebo-controlled trial, which finished the recruitment in June 2016 and is currently ongoing ${ }^{48}$.

\section{CONCLUSIONS}

The recent chain of successes in SPMS and PPMS trials has brought some light to the bleak prospect we used to have in relation to treatment options for PMS. So far, one of these newly tested drugs, the ocrelizumab, has already been approved for patients with $\mathrm{PPMS}^{49}$ and it is likely that more drugs are approved in the near future. Thus, this set of fortunate concatenated events might be meaning a turning point in the history of trials for PMS, enabling us to assess the reasons behind past failures and latest achievements. On the other hand, most of these successes have been modest, mainly restricted to patients with active inflammation and in the context of trials with powerful anti-inflammatory agents. Thus, although inflammation in progressive MS exists and the presence of meningeal follicles is a well-known pathogenic mechanism, there are other processes beyond inflammation that have not been successfully addressed by many of the drugs recently tested. Therefore, it is not surprising that a number of significant failures have also occurred over the previous years, despite a careful choice of the tested drug. 
In sum, it has become clearer that drugs' mechanism of action must tackle the specific pathogenic mechanisms that characterise progressive MS in order to increase the chances of success. Also, the trial populations where new drugs are to be tested should be carefully chosen. Younger populations with shorter disease durations and more rapid progression rates have greater chances of showing active deterioration during the years of the trial, therefore increasing the power to detect treatment effects, should these exist. Finally, outcome measures in both phase 2 and phase 3 trials should be as sensitive as possible to detect treatment effects within a short time frame, and be accompanied by a smart trial design able to maximise the potential of the trial to find effective drugs in a quick and efficient manner. 


\section{REFERENCES}

1. Montalban X, Hauser SL, Kappos L, et al. Ocrelizumab versus Placebo in Primary Progressive Multiple Sclerosis. N Engl J Med. 2016.

2. Kappos L, Bar-Or A, Cree B, et al. Efficacy and safety of siponimod in secondary progressive multiple sclerosis - Results of the placebo controlled, doubleblind, Phase III EXPAND study. ECTRIMS. London, UK2016.

3. Tourbah A, Lebrun-Frenay C, Edan G, et al. MD1003 (high-dose biotin) for the treatment of progressive multiple sclerosis: A randomised, double-blind, placebocontrolled study. Mult Scler. 2016; 22: 1719-31.

4. Chataway J, Schuerer N, Alsanousi A, et al. Effect of high-dose simvastatin on brain atrophy and disability in secondary progressive multiple sclerosis (MSSTAT): a randomised, placebo-controlled, phase 2 trial. Lancet. 2014; 383: 2213-21. 5. Mahad DH, Trapp BD and Lassmann H. Pathological mechanisms in progressive multiple sclerosis. Lancet Neurol. 2015; 14: 183-93.

6. Lublin FD, Reingold SC, Cohen JA, et al. Defining the clinical course of multiple sclerosis: the 2013 revisions. Neurology. 2014; 83: 278-86.

7. Hommes OR, Sorensen PS, Fazekas F, et al. Intravenous immunoglobulin in secondary progressive multiple sclerosis: randomised placebo-controlled trial. Lancet. 2004; 364: 1149-56.

8. Lublin F, Miller DH, Freedman MS, et al. Oral fingolimod in primary progressive multiple sclerosis (INFORMS): a phase 3, randomised, double-blind, placebo-controlled trial. Lancet. 2016; 387: 1075-84.

9. Placebo-controlled multicentre randomised trial of interferon beta-1b in treatment of secondary progressive multiple sclerosis. European Study Group on interferon beta-1b in secondary progressive MS. Lancet. 1998; 352: 1491-7. 10. Freedman MS, Bar-Or A, Oger J, et al. A phase III study evaluating the efficacy and safety of MBP8298 in secondary progressive MS. Neurology. 2011; 77: 1551-60.

11. Warren KG, Catz I, Ferenczi LZ and Krantz MJ. Intravenous synthetic peptide MBP8298 delayed disease progression in an HLA Class II-defined cohort of patients with progressive multiple sclerosis: results of a 24-month double-blind placebocontrolled clinical trial and 5 years of follow-up treatment. Eur J Neurol. 2006; 13: 887-95.

12. Bornstein MB, Miller A, Slagle S, et al. A placebo-controlled, double-blind, randomized, two-center, pilot trial of Cop 1 in chronic progressive multiple sclerosis. Neurology. 1991; 41: 533-9.

13. Hartung HP, Gonsette R, Konig N, et al. Mitoxantrone in progressive multiple sclerosis: a placebo-controlled, double-blind, randomised, multicentre trial. Lancet. 2002; 360: 2018-25.

14. Secondary Progressive Efficacy Clinical Trial of Recombinant Interferon-Beta1a in MSSG. Randomized controlled trial of interferon- beta-1a in secondary progressive MS: Clinical results. Neurology. 2001; 56: 1496-504.

15. Andersen O, Elovaara I, Farkkila M, et al. Multicentre, randomised, double blind, placebo controlled, phase III study of weekly, low dose, subcutaneous interferon beta-1a in secondary progressive multiple sclerosis. J Neurol Neurosurg Psychiatry. 2004; 75: 706-10.

16. Panitch H, Miller A, Paty D, Weinshenker B and North American Study Group on Interferon beta-1b in Secondary Progressive MS. Interferon beta-1b in secondary 
progressive MS: results from a 3-year controlled study. Neurology. 2004; 63: 178895.

17. Leary SM, Miller DH, Stevenson VL, Brex PA, Chard DT and Thompson AJ. Interferon beta-1a in primary progressive MS: an exploratory, randomized, controlled trial. Neurology. 2003; 60: 44-51.

18. Montalban X, Sastre-Garriga J, Tintore $\mathrm{M}$, et al. A single-center, randomized, double-blind, placebo-controlled study of interferon beta-1b on primary progressive and transitional multiple sclerosis. Mult Scler. 2009; 15: 1195-205.

19. McCormack PL and Scott LJ. Interferon-beta-1b: a review of its use in relapsing-remitting and secondary progressive multiple sclerosis. CNS Drugs. 2004; 18: $521-46$.

20. Marriott JJ, Miyasaki JM, Gronseth G, O'Connor PW, Therapeutics and Technology Assessment Subcommittee of the American Academy of N. Evidence Report: The efficacy and safety of mitoxantrone (Novantrone) in the treatment of multiple sclerosis: Report of the Therapeutics and Technology Assessment Subcommittee of the American Academy of Neurology. Neurology. 2010; 74: 146370.

21. Chataway J and investigators M-S. Simvastatin in patients with progressive multiple sclerosis--Authors' reply. Lancet. 2014; 384: 952-3.

22. van der Most PJ, Dolga AM, Nijholt IM, Luiten PG and Eisel UL. Statins: mechanisms of neuroprotection. Prog Neurobiol. 2009; 88: 64-75.

23. Serafini B, Rosicarelli B, Magliozzi R, Stigliano E and Aloisi F. Detection of ectopic B-cell follicles with germinal centers in the meninges of patients with secondary progressive multiple sclerosis. Brain Pathol. 2004; 14: 164-74.

24. Howell OW, Reeves CA, Nicholas R, et al. Meningeal inflammation is widespread and linked to cortical pathology in multiple sclerosis. Brain. 2011; 134: 2755-71.

25. Magliozzi R, Howell OW, Reeves C, et al. A Gradient of neuronal loss and meningeal inflammation in multiple sclerosis. Ann Neurol. 2010; 68: 477-93.

26. Hawker K, O'Connor P, Freedman MS, et al. Rituximab in patients with primary progressive multiple sclerosis: results of a randomized double-blind placebocontrolled multicenter trial. Ann Neurol. 2009; 66: 460-71.

27. Sedel F, Bernard D, Mock DM and Tourbah A. Targeting demyelination and virtual hypoxia with high-dose biotin as a treatment for progressive multiple sclerosis. Neuropharmacology. 2016; 110: 644-53.

28. Gergely P, Nuesslein-Hildesheim B, Guerini D, et al. The selective sphingosine 1-phosphate receptor modulator BAF312 redirects lymphocyte distribution and has species-specific effects on heart rate. Br J Pharmacol. 2012; 167: $1035-47$.

29. Brinkmann V. FTY720 (fingolimod) in Multiple Sclerosis: therapeutic effects in the immune and the central nervous system. Br J Pharmacol. 2009; 158: 1173-82.

30. Lublin FD and Reingold SC. Defining the clinical course of multiple sclerosis: results of an international survey. National Multiple Sclerosis Society (USA) Advisory Committee on Clinical Trials of New Agents in Multiple Sclerosis. Neurology. 1996; 46: 907-11.

31. Wolinsky JS, Narayana PA, O'Connor P, et al. Glatiramer acetate in primary progressive multiple sclerosis: results of a multinational, multicenter, double-blind, placebo-controlled trial. Ann Neurol. 2007; 61: 14-24.

32. Noseworthy JH, Vandervoort MK, Wong CJ and Ebers GC. Interrater variability with the Expanded Disability Status Scale (EDSS) and Functional Systems 
(FS) in a multiple sclerosis clinical trial. The Canadian Cooperation MS Study Group. Neurology. 1990; 40: 971-5.

33. Cutter GR, Baier ML, Rudick RA, et al. Development of a multiple sclerosis functional composite as a clinical trial outcome measure. Brain. 1999; 122 ( Pt 5): 871-82.

34. Ebers GC, Heigenhauser L, Daumer M, Lederer C and Noseworthy $\mathrm{JH}$. Disability as an outcome in MS clinical trials. Neurology. 2008; 71: 624-31.

35. Zajicek J, Ball S, Wright D, et al. Effect of dronabinol on progression in progressive multiple sclerosis (CUPID): a randomised, placebo-controlled trial. Lancet Neurol. 2013; 12: 857-65.

36. Steiner D, Arnold D, Freedman M, et al. Natalizumab versus placebo in patients with secondary progressive multiple sclerosis (SPMS): results from ASCEND, a multicenter, double-blind, placebo-controlled, randomized phase 3 clinical trial. American Academy of Neurology. 2016.

37. Lublin FD, Cofield SS, Cutter GR, et al. Randomized study combining interferon and glatiramer acetate in multiple sclerosis. Ann Neurol. 2013; 73: 327-40. 38. Cohen JA, Coles AJ, Arnold DL, et al. Alemtuzumab versus interferon beta 1a as first-line treatment for patients with relapsing-remitting multiple sclerosis: a randomised controlled phase 3 trial. Lancet. 2012; 380: 1819-28.

39. Coles AJ, Twyman CL, Arnold DL, et al. Alemtuzumab for patients with relapsing multiple sclerosis after disease-modifying therapy: a randomised controlled phase 3 trial. Lancet. 2012; 380: 1829-39.

40. Bevan CJ and Cree BA. Disease activity free status: a new end point for a new era in multiple sclerosis clinical research? JAMA Neurol. 2014; 71: 269-70.

41. Johnson KP, Brooks BR, Cohen JA, et al. Copolymer 1 reduces relapse rate and improves disability in relapsing-remitting multiple sclerosis: results of a phase III multicenter, double-blind placebo-controlled trial. The Copolymer 1 Multiple Sclerosis Study Group. Neurology. 1995; 45: 1268-76.

42. Sedel F, Papeix C, Bellanger A, et al. High doses of biotin in chronic progressive multiple sclerosis: a pilot study. Mult Scler Relat Disord. 2015; 4: 159-69.

43. Kuhle J, Nourbakhsh B, Grant D, et al. Serum neurofilament is associated with progression of brain atrophy and disability in early MS. Neurology. 2017; 88: 826-31.

44. Cawley N, Tur, C. ; Prados, F.; Plantone, D.; Kearney, H.; Abdel - Aziz, K.; Ourselin, S.; Gandini Wheeler - Kingshott, C.A.M.; Miller, D.H.; Thompson, A.J.; Ciccarelli, $\mathrm{O}$. Spinal cord atrophy as a primary outcome measure in phase II trials of progressive multiple sclerosis. Mult Scler Journal (in press). 2016.

45. Fox RJ, Coffey CS, Cudkowicz ME, et al. Design, rationale, and baseline characteristics of the randomized double-blind phase II clinical trial of ibudilast in progressive multiple sclerosis. Contemp Clin Trials. 2016; 50: 166-77.

46. $\quad$ Li DK, Zhao GJ, Paty DW and University of British Columbia MSMRIARGTSSG. Randomized controlled trial of interferon-beta-1a in secondary progressive MS: MRI results. Neurology. 2001; 56: 1505-13.

47. James ND, Sydes MR, Clarke NW, et al. Addition of docetaxel, zoledronic acid, or both to first-line long-term hormone therapy in prostate cancer (STAMPEDE): survival results from an adaptive, multiarm, multistage, platform randomised controlled trial. Lancet. 2016; 387: 1163-77.

48. ClinicalTrials.gov. US National Library of Medicine at the National Institutes of Health. Bethesda, Maryland, U.S. 
49. Food and Drug Administration FDA and US Department of Health and Human Services US.

https://www.fda.gov/NewsEvents/Newsroom/PressAnnouncements/ucm549325.htm. 2017. 
Table 1. Main trials in SPMS

\begin{tabular}{|c|c|c|c|c|c|c|}
\hline $\begin{array}{l}\text { Drug tested } \\
\text { (vs. } \\
\text { placebo) }\end{array}$ & Trial & $\begin{array}{l}\text { Condition } \\
\text { (no. of } \\
\text { patients } \\
\text { randomised) }\end{array}$ & Duration & $\begin{array}{l}\text { Primary } \\
\text { endpoint(s) }\end{array}$ & $\begin{array}{l}\text { Results } \\
\text { on the } \\
\text { primary } \\
\text { endpoint }\end{array}$ & Reference \\
\hline $\begin{array}{l}\text { IFN beta-1b } \\
\text { SC } 8 \text { million } \\
\text { IU eod }\end{array}$ & $\begin{array}{l}\text { Phase } 3 \\
\text { (EUSPMS } \\
\text { study) }{ }^{1}\end{array}$ & $\begin{array}{l}\text { SPMS } \\
(n=718)\end{array}$ & $\begin{array}{l}\text { Early } \\
\text { termination } \\
\text { due to } \\
\text { obvious } \\
\text { superiority } \\
\text { of IFN } \\
\text { (initially } \\
\text { planned: } \\
39 \text { months) }\end{array}$ & $\begin{array}{l}\text { Time to 3- } \\
\text { month CDP } \\
\text { on the } \\
\text { EDSS }^{2}\end{array}$ & Positive & $\begin{array}{l}\text { European } \\
\text { Study Group } \\
\text { on IFN beta- } \\
1 \text { b in SPMS, } \\
\text { Lancet } 1998 \text {, } \\
\text { phase } 3\end{array}$ \\
\hline $\begin{array}{l}\text { IFN beta-1a } \\
\text { SC } 22 \mu \mathrm{g} \text { or } \\
44 \mu \mathrm{g} \text { thrice } \\
\text { weekly }\end{array}$ & $\begin{array}{l}\text { Phase } 3 \\
\text { (SPECTRIMS } \text { study) }^{1}\end{array}$ & $\begin{array}{l}\text { SPMS } \\
(n=618)\end{array}$ & 36 months & $\begin{array}{l}\text { Time to 3- } \\
\text { month CDP } \\
\text { on the } \\
\text { EDSS }\end{array}$ & Negative & $\begin{array}{l}\text { Li et al. } \\
\text { (SPECTRIMS } \\
\text { Study } \\
\text { Group), } \\
\text { Neurology } \\
2001\end{array}$ \\
\hline $\begin{array}{l}\text { IFNb- } 1 \mathrm{~b} \text { SC } \\
250 \mu \mathrm{g} \text { or } \\
160 \mu \mathrm{g} / \mathrm{m}^{2} \text { of } \\
\text { body surface } \\
\text { area eod }\end{array}$ & $\begin{array}{l}\text { Phase } 3 \\
\text { (NASPMS } \\
\text { study) }{ }^{1}\end{array}$ & $\begin{array}{l}\text { SPMS } \\
(n=939)\end{array}$ & $\begin{array}{l}\text { Early } \\
\text { termination } \\
\text { for futility } \\
\text { (initially } \\
\text { planned: } \\
36 \text { months) }\end{array}$ & $\begin{array}{l}\text { Time to 6- } \\
\text { month CDP } \\
\text { on the } \\
\text { EDSS }\end{array}$ & Negative & $\begin{array}{l}\text { Panitch et al. } \\
\text { (North } \\
\text { American } \\
\text { Study Group } \\
\text { on IFN beta- } \\
1 \text { b in SPMS), } \\
\text { Neurology } \\
2004\end{array}$ \\
\hline $\begin{array}{l}\text { IFN beta-1a } \\
\text { IM } \\
60 \mathrm{mcg} / \text { week }\end{array}$ & $\begin{array}{l}\text { Phase } 3 \\
\text { (IMPACT } \\
\text { study) }^{1}\end{array}$ & $\begin{array}{l}\text { SPMS } \\
(n=436)\end{array}$ & 24 months & $\begin{array}{l}\text { Change in } \\
\text { the MSFC } \\
\text { from } \\
\text { baseline to } \\
24 \text { months }\end{array}$ & Positive & $\begin{array}{l}\text { Cohen et al., } \\
\text { Neurology } \\
2002\end{array}$ \\
\hline $\begin{array}{l}\text { IFN beta-1a } \\
\text { SC } \\
22 \mathrm{mcg} / \text { week }\end{array}$ & $\begin{array}{l}\text { Phase } 3 \text { (The } \\
\text { Nordic SPMS } \\
\text { study) }{ }^{1}\end{array}$ & $\begin{array}{l}\text { SPMS } \\
(n=371)\end{array}$ & 36 months & $\begin{array}{l}\text { Time to 6- } \\
\text { month CDP } \\
\text { on the } \\
\text { EDSS } 2\end{array}$ & Negative & $\begin{array}{l}\text { Andersen et } \\
\text { al., JNNP } \\
2004\end{array}$ \\
\hline $\begin{array}{l}\text { Mitoxantrone } \\
\text { IV } 12 \mathrm{mg} / \mathrm{m}^{2} \\
\text { or } 5 \mathrm{mg} / \mathrm{m}^{2} \\
\text { of body } \\
\text { surface } \\
\text { area/3 } \\
\text { months }\end{array}$ & $\begin{array}{l}\text { Phase } 3 \\
\text { (MIMS study) }\end{array}$ & $\begin{array}{l}\text { SPMS or } \\
\text { PRMS } \\
\text { course } \\
(n=188)\end{array}$ & 24 months & $\begin{array}{l}\text { Multivariate } \\
\text { analysis of } \\
\text { five clinical } \\
\text { measures: } \\
\text {-EDSS } \\
\text { changes } \\
\text { (baseline- } \\
\text { final); } \\
\text {-Al changes } \\
\text { (baseline- } \\
\text { final); } \\
\text {-No. of } \\
\text { treated } \\
\text { relapses; } \\
\text {-Time to first } \\
\text { treated } \\
\text { relapse; } \\
\text {-Change in } \\
\text { standardised } \\
\text { neurological } \\
\text { status; }\end{array}$ & Positive & $\begin{array}{l}\text { Hartung et } \\
\text { al., Lancet } \\
2002\end{array}$ \\
\hline
\end{tabular}




\begin{tabular}{|c|c|c|c|c|c|c|}
\hline $\begin{array}{l}\text { IVIG } \\
1 \mathrm{~g} / \mathrm{Kg} / \text { month }\end{array}$ & $\begin{array}{l}\text { Phase 3 } \\
\text { (ESIMS } \\
\text { study) }{ }^{3}\end{array}$ & $\begin{array}{l}\text { SPMS } \\
(n=318)\end{array}$ & 24 months & $\begin{array}{l}\text { Time to 3- } \\
\text { month CDP } \\
\text { on the } \\
\text { EDSS }{ }^{2} \\
\end{array}$ & Negative & $\begin{array}{l}\text { Hommes et } \\
\text { al., Lancet } \\
2004\end{array}$ \\
\hline $\begin{array}{l}\text { MBP8298 IV } \\
500 \mathrm{mg} / 6 \\
\text { months }\end{array}$ & Phase 2 & SPMS $(n=32)$ & 24 months & $\begin{array}{l}\text { Change in } \\
\text { the EDSS } \\
\text { from } \\
\text { baseline to } \\
24 \text { months }\end{array}$ & Negative $^{4}$ & $\begin{array}{l}\text { Warren et al., } \\
\text { Eur J Neurol } \\
2006\end{array}$ \\
\hline $\begin{array}{l}\text { MBP8298 IV } \\
500 \mathrm{mg} / 6 \\
\text { months }\end{array}$ & $\begin{array}{l}\text { Phase 3 } \\
\text { (MAESTRO } \\
\text { study) }\end{array}$ & $\begin{array}{l}\text { SPMS } \\
(n=612)\end{array}$ & 24 months & $\begin{array}{l}\text { Time to 6- } \\
\text { month CDP } \\
\text { on the } \\
\text { EDSS }^{2}\end{array}$ & Negative & $\begin{array}{l}\text { Freedman et } \\
\text { al., Neurology } \\
2011\end{array}$ \\
\hline $\begin{array}{l}\text { Lamotrigine } \\
\mathrm{PO} \\
400 \mathrm{mg} / \mathrm{day}\end{array}$ & Phase 2 & $\begin{array}{l}\begin{array}{l}\text { SPMS } \\
(n=120)\end{array}\end{array}$ & 24 months & $\begin{array}{l}\text { Rate of } \\
\text { change of } \\
\text { partial } \\
\text { (central) } \\
\text { cerebral } \\
\text { volume over } \\
24 \text { months }\end{array}$ & Negative & $\begin{array}{l}\text { Kapoor et al., } \\
\text { Lancet } \\
\text { Neurol } 2010\end{array}$ \\
\hline $\begin{array}{l}\text { Dronabinol } \\
\text { PO (max. } \\
\text { dose: } \\
\text { 28mg/day, } \\
\text { titrated } \\
\text { against } \\
\text { bodyweight }\end{array}$ & $\begin{array}{l}\text { Phase } \\
\text { unspecified } \\
\text { (CUPID } \\
\text { study) }\end{array}$ & $\begin{array}{l}\text { SPMS } \\
(n=302), \\
\text { PPMS } \\
(n=191)\end{array}$ & 36 months & $\begin{array}{l}\text {-Time to 6- } \\
\text { month CDP } \\
\text { on the } \\
\text { EDSS } \\
\text {-Change in } \\
\text { the MSIS-29- } \\
\text { PHYS from } \\
\text { baseline to } \\
36 \text { months }\end{array}$ & Negative & $\begin{array}{l}\text { Zajicek et al., } \\
\text { Lancet } \\
\text { Neurol } 2013\end{array}$ \\
\hline $\begin{array}{l}\text { Simvastatin } \\
\text { PO } \\
80 \mathrm{mg} / \text { day }\end{array}$ & Phase 2 & $\begin{array}{l}\text { SPMS } \\
(n=140)\end{array}$ & 24 months & $\begin{array}{l}\text { Annualised } \\
\text { rate of } \\
\text { whole-brain } \\
\text { atrophy }\end{array}$ & Positive & $\begin{array}{l}\text { Chataway et } \\
\text { al., Lancet } \\
2014\end{array}$ \\
\hline $\begin{array}{l}\text { Natalizumab } \\
\text { IV } 300 \mathrm{mg} / 4 \\
\text { weeks }\end{array}$ & $\begin{array}{l}\text { Phase } 3 \\
\text { (ASCEND } \\
\text { study) }\end{array}$ & $\begin{array}{l}\text { SPMS } \\
(n=887)\end{array}$ & 24 months & $\begin{array}{l}\text { Composite } \\
\text { outcome: 6- } \\
\text { month CDP } \\
\text { on EDSS }{ }^{2} \text {, or } \\
\text { TWT } \\
(\geq 20 \%) \text {, or } \\
\text { NHPT } \\
(\geq 20 \%)\end{array}$ & Negative & $\begin{array}{l}\text { Steiner et al., } \\
\text { AAN } 2016\end{array}$ \\
\hline $\begin{array}{l}\text { Biotin PO } \\
100 \mathrm{mg} / 8 \mathrm{~h}\end{array}$ & Phase 2 & $\begin{array}{l}\text { Progressive } \\
\text { MS: SPMS } \\
(n=99) \text { or } \\
\text { PPMS }(n=55)\end{array}$ & 12 months & $\begin{array}{l}\text { Proportion of } \\
\text { patients } \\
\text { with } \\
\text { improvement } \\
\text { of MS- } \\
\text { related } \\
\text { disability }{ }^{6} \text { at } \\
\text { month } \\
9 \text {, confirmed } \\
\text { at month } 12\end{array}$ & Positive & $\begin{array}{l}\text { Tourbah et } \\
\text { al., MSJ } 2016\end{array}$ \\
\hline $\begin{array}{l}\text { Siponimod } \\
\text { PO 2mg/day }\end{array}$ & $\begin{array}{l}\text { Phase 3 } \\
\text { (EXPAND } \\
\text { study) }\end{array}$ & $\begin{array}{l}\text { SPMS } \\
(n=1105)\end{array}$ & 37 months & $\begin{array}{l}\text { Time to 3- } \\
\text { month CDP } \\
\text { on the } \\
\text { EDSS }\end{array}$ & Positive & $\begin{array}{l}\text { Kappos L et } \\
\text { al. ECTRIMS } \\
2016\end{array}$ \\
\hline
\end{tabular}

Table 1 (footnote). 
1: The rationale for the phase 3 trials with IFNb in SPMS was provided by the results of trials carried out in RRMS; 2: The definition of EDSS progression depends on the baseline EDSS score; 3: The rationale for the ESIMS trial was provided by the results of uncontrolled studies and placebocontrolled trials in RRMS; 4: Although the results for the main analysis were negative, in the subgroup of 20 patients with HLA haplotypes DR2 and/or DR4, MBP8298 treatment had a significant effect on the primary endpoint; 5: The rationale for the MAESTRO study was provided by the results of the subgroup analysis with HLA haplotypes DR2 and/or DR4; 6: Improvement was defined as: decrease of $\geq 0.5$ point or $\geq 1$ point in EDSS (if baseline score was $6-7$ or $4.5-5.5$, respectively) or a $\geq 20 \%$ decrease in timed walk test (TWT) time, compared with the best EDSS or TWT value recorded at either the screening or the randomisation visit.

Abbreviations: Al: ambulation index; EDSS: expanded disability status scale; CDP: confirmed disability progression; IFNb-1a/1b: interferon beta 1a/1b; IV: intravenous; MSFC: multiple sclerosis functional composite; MSIS-29-PHYS: physical impact subscale of the 29-item multiple sclerosis impact scale; NHPT: nine-hole peg test; PO: per oral; PPMS: primary progressive multiple sclerosis; PRMS: progressive-relapsing MS; RRMS: relapsing-remitting MS; SC: subcutaneous; SPMS: secondary progressive MS; TWT: timed walk test; 
Table 2. Main trials in PPMS

\begin{tabular}{|c|c|c|c|c|c|c|}
\hline $\begin{array}{l}\text { Drug tested } \\
\text { (vs. } \\
\text { placebo) }\end{array}$ & Trial & $\begin{array}{l}\text { Condition } \\
\text { (no. of } \\
\text { patients } \\
\text { randomised) }\end{array}$ & Duration & $\begin{array}{l}\text { Primary } \\
\text { endpoint }\end{array}$ & $\begin{array}{l}\text { Results } \\
\text { on the } \\
\text { primary } \\
\text { endpoint }\end{array}$ & Reference \\
\hline $\begin{array}{l}\text { GA SC } \\
15 \mathrm{mg} / 12 \mathrm{~h}\end{array}$ & Phase 2 & $\begin{array}{l}\text { Chronic } \\
\text { progressive } \\
\text { MS ( } n=106) ; \\
\text { out of these, } \\
31 \text { had PPMS } \\
\text { ( } n=23 \text { ) or } \\
\text { 'transitional } \\
\text { progressive } \\
\text { MS' }(n=8)\end{array}$ & 24 months & $\begin{array}{l}\text { Time to } \\
\text { confirmed } \\
\text { progression } \\
\text { on the } \\
\text { EDSS }\end{array}$ & Negative $^{2}$ & $\begin{array}{l}\text { Bornstein } \\
\text { et al., } \\
\text { Neurology } \\
1991\end{array}$ \\
\hline $\begin{array}{l}\text { GA SC } \\
20 \mathrm{mg} / \text { day }\end{array}$ & $\begin{array}{l}\text { Phase } 3 \\
\text { (PROMiSe } \\
\text { study) }\end{array}$ & $\begin{array}{l}\text { PPMS } \\
(\mathrm{n}=943)\end{array}$ & $\begin{array}{l}\text { Early } \\
\text { termination } \\
\text { for futility } \\
\text { (initially } \\
\text { planned: } \\
36 \\
\text { months) }\end{array}$ & $\begin{array}{l}\text { Time to 3- } \\
\text { month CDP } \\
\text { on the } \\
\text { EDSS }^{1}\end{array}$ & Negative & $\begin{array}{l}\text { Wolinsky } \\
\text { et al., Ann } \\
\text { Neurol } \\
2007\end{array}$ \\
\hline 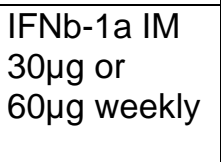 & Phase 2 & PPMS $(n=50)$ & 24 months & $\begin{array}{l}\text { Time to 3- } \\
\text { month CDP } \\
\text { on the } \\
\text { EDSS }{ }^{1}\end{array}$ & Negative & $\begin{array}{l}\text { Leary et } \\
\text { al., } \\
\text { Neurology } \\
2003\end{array}$ \\
\hline $\begin{array}{l}\text { IFNb-1b SC } \\
8 \mathrm{MIU} \text { eod }\end{array}$ & Phase 2 & $\begin{array}{l}\text { PPMS and } \\
\text { 'transitional } \\
\text { progressive } \\
\text { MS' }(n=73)\end{array}$ & 24 months & $\begin{array}{l}\text { Time to 3- } \\
\text { month CDP } \\
\text { on the } \\
\text { EDSS }\end{array}$ & Negative & $\begin{array}{l}\text { Montalban } \\
\text { et al., MSJ } \\
2009\end{array}$ \\
\hline $\begin{array}{l}\text { Rituximab } \\
\text { IV } \\
1000 \mathrm{mg} / 24 \\
\text { weeks }\end{array}$ & $\begin{array}{l}\text { Phase 2/3 } \\
\text { (OLYMPUS } \\
\text { study) }\end{array}$ & $\begin{array}{l}\text { PPMS } \\
(n=439)\end{array}$ & 96 weeks & $\begin{array}{l}\text { Time to 3- } \\
\text { month CDP } \\
\text { on the } \\
\text { EDSS }{ }^{1}\end{array}$ & Negative $^{3}$ & $\begin{array}{l}\text { Hawker et } \\
\text { al., Ann } \\
\text { Neurol } \\
2009\end{array}$ \\
\hline $\begin{array}{l}\text { Fingolimod } \\
\text { PO } \\
0.5 \mathrm{mg} / \text { day }\end{array}$ & $\begin{array}{l}\text { Phase } 3 \\
\text { (INFORMS } \\
\text { study) }^{4}\end{array}$ & $\begin{array}{l}\text { PPMS } \\
(\mathrm{n}=970)\end{array}$ & 36 months & $\begin{array}{l}\text { Composite } \\
\text { endpoint: } \\
\text { Time to 3- } \\
\text { month CDP } \\
\text { on either } \\
\text { EDSS, or } \\
\text { TWT, or } \\
\text { NHPT }\end{array}$ & Negative & $\begin{array}{l}\text { Lublin et } \\
\text { al., Lancet } \\
2016\end{array}$ \\
\hline $\begin{array}{l}\text { Ocrelizumab } \\
\text { IV } 600 \mathrm{mg} \\
\text { (300mg x2) } \\
\text { /24 weeks }\end{array}$ & $\begin{array}{l}\text { Phase 3 } \\
\text { (ORATORIO } \text { study) })^{5}\end{array}$ & $\begin{array}{l}\text { PPMS } \\
(n=732)\end{array}$ & 120 weeks & $\begin{array}{l}\text { Percentage } \\
\text { of patients } \\
\text { with 3- } \\
\text { month CDP } \\
\text { on the } \\
\text { EDSS } \\
1,6\end{array}$ & Positive & $\begin{array}{l}\text { Montalban } \\
\text { et al., N } \\
\text { Engl J } \\
\text { Med. } 2016\end{array}$ \\
\hline
\end{tabular}


Table 2 (footnote).

1: The definition of EDSS progression depends on the baseline EDSS score; 2: In the subset of 31 patients with either PPMS or transitional progressive MS, some hint of efficacy was observed; this motivated the phase 3 trial; 3: In the subgroup of 72 patients with age $<51$ years and presence of gadolinium-enhancing lesions in the MRI, rituximab significantly delayed progression of disability (vs. placebo); 4: The rationale for the INFORMS trial was provided by in-vitro and in-vivo studies that suggested that fingolimod could inhibit neurodegeneration. No phase 2 trial was performed with fingolimod in PPMS; 5: The rationale for the ORATORIO trial was provided by the results of the subgroup analysis of the OLYMPUS trial (in younger patients with inflammatory activity). No phase 2 trial was performed with ocrelizumab in PPMS; 6: Although the primary endpoint was the percentage of patients with CDP, this percentage was obtained through a time-to-event analysis.

Abbreviations: EDSS: expanded disability status scale; CDP: confirmed disability progression; IFNb1a/1b: interferon beta 1a/1b; IV: intravenous; NHPT: nine-hole peg test; PO: per oral; PPMS: primary progressive multiple sclerosis. 